\title{
THE IDENTITY OF THE PERPETRATOR OF THE CRIME AS AN INDIVIDUALIZATION OF PUNISHMENT
}

Alexandra Yu. Bokovnya ${ }^{1}$

Fedor R. Sundurov ${ }^{2}$

\begin{abstract}
The article examines the phenomenon of the identity of the perpetrator of a crime in the mechanism of individualization of criminal punishment. It is pointed out that although the criminal act acts as the main dimension of the indentity of the perpetrator of a crime, it is of fundamental importance in the punishment individualization mechanism to take into account the individual diversity inherent in any perpetrator's personality that may be reflected in the crime or not characterize it.
\end{abstract}

Keywords: crime; criminal law; criminal liability.

\section{Introduction}

Individualization is a derived concept from the word "individual", which, in turn, characterizes a person as a separate identity. The basis of the individualization of social phenomena, including criminal punishment, is the person. The individualization of punishment can be likened to a medicine intended to treat a social disease. When individualizing punishment, the whole variety of properties and manifestations of the perpetrator's identity, including the individual signs of a crime, the circumstances of its commission, are taken into account, and all this makes it possible to choose a fair and reasonable punishment in each particular case. The individualization of punishment, along with its differentiation in the law, is a kind of "key" to justice and its social effectiveness. Therefore, the importance of taking into account the perpetrator's identity in this very complex mechanism is difficult to overestimate.

\section{Materials and methods}

\footnotetext{
1 Kazan Federal University, Faculty of Law, Criminal law Department, Kazan, Russia, e-mail: at240886@gmail.com, phone: 8(843)2337103

2 Kazan Federal University, Faculty of Law, Criminal law Department, Kazan, Russia, e-mail: kafedra.ksu@yandex.ru, phone: 8(843)2337103
} 
This article is based on the following materials: provisions of Articles 2, 4, 6, 15, 20, 60, 61, 62, 63, 64, $68,73,75,76,82,89$ of the Criminal Code of the Russian Federation, $§ 46,49$, 50 of the Criminal Code of the Federal Republic of Germany, Articles 62, 63 of the Criminal Code of the Republic of Belarus, Article 52 of the Criminal Code of the Republic of Kazakhstan, Article 53 of the Criminal Code of Poland, regulating personal circumstances in the system of individualization means concerning punishment.

The reliability of the results obtained is stipulated on the basis of the analysis of significant array of legislation, materials of judicial practice, statistical data on the use of punishments, as well as the use of various methods of studying legal phenomena: logical, system-structural, historical-legal, comparative-legal, etc.

\section{Results and discussion}

The identity of the perpetrator of a crime serves simultaneously as a criterion for the individualization of punishment and its addressee. And at the same time, it is a kind of toolkit of justice punishment since, all other things being equal, a guilty person who is characterized by a negative attitude should be assigned a more severe punishment than a person with a rather positive characterization of pre-criminal behavior. The basis of punishment individualization is the idea of coordinating the punishment (implementation of the punishment) and the correction of the convict. As S. Berard reasonably notes, the individualization of punishment implies a balance between the gravity of the crime and the personality of the criminal, on the one hand, and the punishment to be applied, on the other hand. [Berar, 2018]

At the same time, the individualization of punishment shows practical significance with a corresponding differentiation of criminal responsibility, the limits of which should allow imposing punishment, taking into account the individual signs of crime and the perpetrator's identity, but on the other hand, it is impossible to individualize punishment indefinitely, thereby violating the principle of equality by law. In other words, it should be carried out taking into account the socially significant personal features of the 
perpetrator and in the interests of achieving the goals of punishment. In both domestic and foreign literature, the practice of clearly excessive prison sentences in the US [Suess, 2013] is criticized, and this phenomenon, in our opinion, is due to the prevalence of differentiation over the individualization of criminal punishment in this country.

The core of individualization is the punishment specification, taking into account the perpetrator's identity. Many of the provisions of the Criminal Code of the Russian Federation are saturated with personal potential, starting with exemption from criminal liability to conditional early release from serving a life sentence.

The criminal law of Russia does not implement a purely formal approach to the interpretation of a crime and the assessment of the perpetrator's identity, the degree of public danger of which is not always fully correlated with the nature and public danger of the crime committed. The study of judicial practice shows that the persons guilty of committing crimes have different ways, the same crimes are committed under different circumstances, have different psychological content, there is also an ambiguous relationship to their criminal acts.

The main social dimension of a guilty person is a crime in criminal law, it usually expresses its antisocial charge or direction, and at the same time, when the punishment is individualized, it is important to take into account the individual features of the person guilty, which can be reflected in a particular way or not to characterize it. The fundamental importance of the perpetrator's identity in criminal law is also manifested in the goal setting of punishment; Part 2 of Article 43 of the Criminal Code prescribes for the courts to impose punishment in each particular case, taking into account the possibility of correcting the convicted person and the achievement of other purposes of punishment. Without taking into account the socio-legal assessment of his/her identity, the achievement of such a result is impossible. Although it should be noted that there are many contradictions in its objectives regarding justice and expediency, utility for the society or only for the convicted person, humanism regarding the guilty or the victim as in the punishment [Sundurov and Talan, 2015]. 
The literature suggests various definitions of the person in general and the guilty person (offender). Thus, Yu.M. Antonyan, V.N. Kudryavtsev and V.E. Eminov define personality as a set of socially significant negative properties integrated into it, formed in the process of diverse and systematic interactions with other people. The identity of the perpetrator of a crime, writes L.L. Kruglikov, is a collective concept, encompassing the social nature of human, his/her psychological and biological features. In the literature, personality is also understood as a feature of a socially disintegrated person, consisting of a set of negative properties that influence the commission of a crime in combination with the situational circumstances [Antonyan, Kudryavtsev and Eminov, 2004]. It is defined as both the "social face of the person who has committed the crime" and "the carrier of specific motives". The perpetrator's identity in criminal law is a type of human personality, and moreover, it is not some kind of conglomeration of properties, features, but a certain systemstructural formation of those properties, manifestations that have criminal law significance.

$\begin{array}{rr} & 175 \\ \text { Personality is an }\end{array}$

interdisciplinary concept; it is the object of research in philosophy, sociology, general and social psychology, psychiatry, and jurisprudence. In the field of jurisprudence, it is studied from the standpoint of various branches of law - criminology, victimology, deviantology, etc. In each of the branches of science, personality is studied on the basis of their inherent tools and in accordance with their tasks. For example, in criminology, the perpetrator's identity should be interpreted from the point of view of clarifying the etiology, mechanism of criminal behavior, identifying the causes and conditions causing it; in the penal law - from the standpoint of the effectiveness of the correction of convicted person, warning him/her of new crimes; in the criminal law - it should be studied those parts or signs that have criminal-legal value, in particular, when dealing with issues such as criminal prosecution or descent from it, differentiation and individualization of the implementation forms of this responsibility or just punishment, exemption from serving the sentence, application of other (besides 
punishment) measures of a criminal law nature, etc. On this basis, the perpetrator's identity in criminal law can be defined as a specific system of socially significant, criminal-legal value properties of a person, who commits or has already committed a crime, whose interaction with the environment has led to the commission of a crime. The features of the perpetrator's identity different in nature have different criminally-legal significance: mental (limited responsibility), individual psychological (affect, repentance), social psychological (behavior in family, public places), sociological (committing a crime in a public disaster), criminological (the relationship of the perpetrator with the victim), and criminal law (recidivism). They can be antisocial (criminogenic), socially useful or neutral.

As the main and universal criterion, the perpetrator's identity imparts individualization not only of punishment, but also of criminal responsibility, purposeful in terms of the criminal law impact on it. Individualization in this sense is not an end in itself, it should be carried out in the interests of achieving the correction of the convicted person and other goals of punishment, preventing the guilty from committing new crimes. Therefore, the implementation of the personal potential of all the provisions of criminal law has its addressee in the form of the perpetrator's identity, and the more consistently it is implemented, the more effective its norms become.

The personality features of the guilty person predetermine the specific nature of the punitive or non-punitive influence on him/her, including the fact of bringing to criminal responsibility. Thus, according to Part 3 of Article 20 of the Criminal Code of the Russian Federation, if a minor has reached the age of bringing to criminal responsibility, but he/she could not fully understand the actual nature and social danger of his/her actions (inaction) or lead them due to a lag in his/her psychological development unrelated to mental disorder, while committing a socially dangerous act, he/she is not subject to criminal liability. According to the Criminal Code of the Republic of Belarus, in cases stipulated by the Special Part of the Code, criminal responsibility for a crime that does not pose a great public danger comes, if the 
act was committed within a year after the imposition of an administrative or disciplinary penalty for the same violation. [Bluvshtein, 1978] The Russian legislator, in our opinion, "hurried" with the refusal of administrative prejudice, although later it actually admitted its mistake when introducing it into the edition, for example, Part 1 of Article 282 of the Criminal Code of the Russian Federation, which stipulates responsibility for inciting hatred or hostility, as well as for the humiliation of the honor and dignity of the individual.

When exempt from criminal liability in the presence of active repentance, reconciliation with the victim, as well as in the commission of criminal acts in the field of economic activity, the norms stipulating this exemption are directly addressed to the perpetrator of the crime. In Articles 75 and 76 of the Criminal Code of the Russian Federation, the legislator limits the exemption from criminal liability to only one objective circumstance - the commission of a minor or moderate crime; and in Article 761 of the Criminal Code of the Russian Federation - the commission of only those crimes stipulated in Articles $198-199^{1}, 199^{2}$ and $199^{3}$ of the Criminal Code of the Russian Federation. The resolution of the issue of exemption from criminal liability essentially depends entirely on the assessment by the court or law enforcement authority of the guilty person. We also note that it applies only when the criminal justice tasks can be accomplished and the corresponding goals are achieved for the perpetrator of the crime. Practice in Russia, as well as in other states, has shown that a greater social effect can be achieved not through the use of punitive measures, but with exemption from criminal responsibility or only punishment in certain and quite a few cases [Balafendiyev, 2017]. The use of punitive or non-punitive criminallegal measures to persons who have committed not serious crimes for the first time, should mainly be determined by the personality features of the perpetrator, the level of his/her antisocial contamination.

Personality features as an addressee of individualization of criminal punishment should be taken into account when determining not only the term or size, but also the type of punishment. As you know, the sanctions 
of the norms of the Special Part of the Criminal Code of the Russian Federation and many other states are alternative, they stipulate several types of punishment, and cumulative, combining basic and additional types of punishment. In addition, there are relatively defined terms and sizes of punishments in all sanctions. Features of the regulation of punishments in the articles of the Special Section of the Criminal Code of the Russian Federation create preconditions for the individualization of punishment and increase in their targeting, the appointment of such penalties that would ensure positive results in achieving the goals of punishment. At the same time, the implementation of repression saving principle, which is based on the requirement to take into account the perpetrator's identity in sentencing, is of no small importance. As stipulated in Part 1 of Article 30 of the Criminal Code, the stricter type of punishment stipulated for the crime committed can be imposed only if a less severe type of punishment cannot ensure the achievement of punishment objectives.

And especially the paramount importance of taking into account the perpetrator's identity is attached to the regulation of the purpose of punishment by the court, when it is individualized. As one of the general principles, that is, the fundamental and universal rules for appointment, the requirement to take into account the perpetrator's identity is recognized, along with the nature and degree of public danger of the crime committed (Part 3 of Article 60 of the Criminal Code of the Russian Federation). Although, in our opinion, the main criterion for the justice of punishment is the severity of offense, but without taking into account the perpetrator's identity, it is also not possible to impose a fair and expedient punishment at the same time. The fact that it is addressed to the guilty person follows from Part 3 of Article 60 of the Criminal Code of the Russian Federation, according to which, when sentencing, the court shall take into account its influence on the correction of the convict and the living conditions of his/her family (by the way, this is also his/her personal feature).

Given the universal nature of this common beginning, personal accounting is required when imposing 
punishment for the commission of any crime and every guilty person.

It is fully justified to specify the perpetrator's identity when taking on additional punishments in the form of deprivation of a special, military or honorary title, class rank and state awards (Article 48 of the Criminal Code of the Russian Federation), deprivation of the right to hold certain positions or being engaged in certain activities (Article 47 of the Criminal Code of the Russian Federation), as well as in the regulation of sentencing in the presence of mitigating circumstances (Article 62 of the Criminal Code of the Russian Federation), appointment of a milder punishment than those stipulated by law (Article 64 of the Criminal Code of the Russian Federation), implying punishment in case of relapse crimes (Article 68 of the Criminal Code of the Russian Federation).

The orientation on the targeted nature of the punishment is also seen in the fact that not only punishment is defined as the corresponding set of legal restrictions and (or) deprivation in the same Article of the Criminal Code of the Russian Federation (Article 43), but it also sets out its goals directly related to the convicted person. This indicates that the perpetrator's identity of the crime is the main addressee of punishment.

The significant potential for the individualization of punishment lies in the circumstances mitigating and aggravating it, since the legislator identifies the most essential circumstances during their regulation, which substantively characterize the perpetrator's identity, as well as his/her crime. At the same time, it is impossible not to draw attention to the fact that, in regulating the mitigating circumstances, preference over aggravating factors is given to a particular personality trait of the perpetrator. In this regard, it seems to us unreasonable that the legislator's refuses to recognize a slander of a knowingly innocent person as those who has committed a crime or as a person who has previously committed a crime as an aggravating circumstance, as envisaged in the last Soviet Criminal Code (1960). It is thought that not only a relapse, but repeated commission of intentional crimes should aggravate punishment before the conviction. It also seems fair to recognize as a mitigating circumstance a sincere repentance, the presence of which essentially indicates a 
"premature" correction of the repentant person.

Personal mitigating and aggravating circumstances make it possible to give a correct and more substantive assessment of the perpetrator's identity and, with its consideration, to appoint an expedient punishment, the implementation of which would contribute to the achievement of its goals.

More attention is paid to the regulation of the circumstances characterizing the perpetrator's identity in the Criminal Code of Germany. Part 3 $\S 46$ states that when imposing a punishment, the motives and goals of a person who has committed the crime, the way of thinking, revealed in the criminal act committed by him/her, and the will shown in its commission, his/her behavior after the act, the previous life of the offender, his/her personal and material conditions should be taken into account. More fully, these circumstances are set out in Article 53 of the Criminal Code of Poland; the court, in particular, is instructed to take into account the precautionary and educational goals, motivation, personal features and conditions of life of the perpetrator, way
180

of life before committing the crime, and behavior after it has been taken.

The increased attention to the regulation of the circumstances characterizing the perpetrator's identity is not an accidental phenomenon, since they allow giving the most correct assessment of the punishment to the guilty person, being optimal in terms of achieving relevant goals.

\section{Conclusions}

As a result, we should note that the basis for the individualization of criminal punishment is the variety of circumstances that characterize both a specific crime and the perpetrator's identity. The individuality and uniqueness of crimes and the perpetrator's identity necessitate the individualization of punishment.

The perpetrator's or the offender's identity is a universal and comprehensive criterion for the individualization of punishment, since it is not only a crime, and the circumstances of its commission are crucially determined by the peculiarities of his/her personality. A more consistent regulation of the circumstances characterizing the perpetrator's identity 
will increase the focus of the criminal law measures applied. From these positions, it seems expedient to expand the aggravating circumstances characterizing the perpetrator's identity in the Criminal Code of the Russian Federation, for example, to admit as such a slander of a knowingly innocent person, commission by a person of two or more intentional crimes before conviction, commission of a crime with mercenary or other base motives, etc.; and as mitigating - sincere repentance, commission of a crime by an elderly person, fulfillment of a special task of preventing or disclosing criminal activity.

\section{Summary}

Thus, it can be concluded that individualization should predetermine the application of fair and expedient punishment. It is based on taking into account the individual signs of a crime and the perpetrator's identity. Since the perpetrator's identity performs two interrelated functions, that is, it serves as a criterion and addressee of individualization of punishment, therefore the implementation of the first function should predetermine the implementation of the second, and they shall ensure the successful achievement of the goals of punishment together.

\section{References}

Antonyan Yu.M., Kudryavtsev V.N., Eminov V.E. (2004). The Perpetrator's Identity. - SPb.: Legal Center Press, 2004. P. 12.

Balafendiyev A.M. (2017). Exemption from Criminal Liability due to Positive Post-Criminal Behavior. - Kazan: Publishing House of the Kazan University, 2017. P. 4-5.

Berar C. (2018). The individualization of punishment according to the new criminal code. Proceedings of the International Conference «Recent Advances in Economic and Social Research» (13-14 May, 2015), Bucharest, Romania. [Electronic resource] Retrieved on 13 June 2018 from

URL: http://www.ipe.ro/RePEc/WorkingPaper s/wpconf151203.pdf

Bluvshtein Yu.D. (1978). The Concept of the Perpetrator's Identity / State and Law. 1978. No. 8. P. 98. 
Suess M.K. (2013). Punishment in the

State of Nature: John Locke and

Criminal Punishment in the United

States of America / Matthew K. Suess,

Washington University Jurisprudence

Review, 2015. №7 (2). P. 367-397;

Albrecht H.J. Sentencing in Germany:

Explaining Long-Term Stability in the

Structure of Criminal Sanctions and

Sentencing. - Law and Contemporary

Problems, 2013. № 76 (1). P. 211-236.

Sundurov F.R., Talan M.V. (2015).

Punishment in Criminal Law: Study

Guide. - M.: Statut, 2015. P. 69 